\title{
PENGELOLAAN DAN PENGUKURAN KINERJA KARYAWAN PELATIHAN INDUKSI DI HOME SCHOOLING KAK SETO
}

\author{
Eko Wanidison ${ }^{1}$, Mustofa Kamil ${ }^{2}$ \\ Email: eko.wanidison@upi.edu
}

\begin{abstract}
ABSTRAK
Pendekatan homeschooling berbeda dengan sekolah, maka pembentukan, penyiapan, dan pengembangan sumber daya manusia di Home schooling Kak Seto (HSKS) menjadi sorotan penting. Baik tutor maupun tenaga kependidikan di HSKS harus mampu memfasilitasi keberagaman dan keunikan para homeschooler dengan prinsip homeschooling. Lebih dari itu, HSKS pun harus mampu menyediakan informasi dan pendidikan bagi orang tua untuk melakukan bimbingan terhadap anaknya di rumah. penelitian ini dilakukan untuk melihat bagaimana pengelolaan model pelatihan induksi, dan penilaian kinerja Sumber Daya Manusia di Homeschooling Kak Seto dengan cara pendekatan kualitatif menggunakan instrumen penelitian observasi, wawancara, kuisioner atau angket yang disebar menggunakan google doc, dan dokumentasi. Konsep yang dijadikan kajian teori dalam penilitian ini adalah model pengelolaan, kinerja karyawan, dan homeschooling. model pengelolaan pelatihan di homeschooling kak seto melibatkan peserta dalam perencanaan, pelaksanaan, dan evaluasi kemudian kinerja sumber daya manusia di Homeschooling kak seto sudah memenuhi dengan kebutuhan lembaga.
\end{abstract}

Kata kunci: Home schooling, pelatihan induksi, kinerja sumber daya manusia

\section{PENDAHULUAN}

Latar belakang

Guru besar UPI, Prof. Dr. Ace Suryadi, M.Sc., Ph.D menyatakan bahwa fungsi dari pengembangan SDM adalah penyiapan tenaga kerja terdidik, terampil, terlatih, dan profesional yang akan bermanfaat di masa mendatang. Semakin tinggi pendidikan atau pelatihan yang diikuti seseorang, semakin tinggi tingkat produktivitasnya, dan semakin terdidik seseorang semakin tinggi pula pemahamannya, baik terhadap kesehatan, partisipasi politik, toleransi, maupun pada penciptaan kehidupan yang harmonis. Tidak ada faktor yang lebih berkepentingan dibandingkan dengan membentuk kualitas Sumber Daya Manusia. Terlebih lagi dengan adanya persaingan global dan pasar bebas yang menuntut berbagai keahlian, seperti literasi teknologi dan keuangan. Banyak komunitas atau lembaga di masyarakat yang secara aktif terus menerus melakukan aktivitasnya, baik di bidang pendidikan maupun bukan, yang berusaha meningkatkan kapasitas pengelola untuk menjadi lebih profesional. Salah satunya adalah yang dilakukan oleh Yayasan Homeschooling Kak Seto (HSKS).

HSKS didirikan atas pemikiran bahwa setiap anak mempunyai hak yang sama untuk mendapatkan pendidikan dan setiap anak sedapat mungkin memperoleh pendidikan yang layak bagi dirinya. Gagasan homeschooling adalah memberikan kebebasan pada orang tua dan anak untuk menentukan cara yang paling efektif mengejar mimpi terbaiknya, tanpa paksaan atau tekanan eksternal. Berbeda dengan sekolah sebagai salah satu sarana pendidikan, homeschooling memiliki flesksibilitas dalam segala pengelolaannya, selama tidak melanggar nilai agama, peraturan pendidikan nasional, dan norma sosial. Ditentukan sendiri oleh orang tua dan anak, homeschooling dianggap sebuah lembar kertas putih yang siap di lukis dengan apapun sesuai keinginan dan kebutuhan orang tua dan anak. Tantangan terbesar adalah 
menyiapkan keluarga menjadi pembelajar. Praktisi homeschooling harus mampu mencurahkan energi dan perhatian pada anak-anaknya sendiri. Karena pendekatan homeschooling berbeda dengan sekolah, maka pembentukan, penyiapan, dan pengembangan sumber daya manusia di HSKS menjadi sorotan penting. Baik tutor maupun tenaga kependidikan di HSKS harus mampu memfasilitasi keberagaman dan keunikan para homeschooler dengan prinsip homeschooling. Lebih dari itu, HSKS pun harus mampu menyediakan informasi dan pendidikan bagi orang tua untuk melakukan bimbingan terhadap anaknya di rumah. Oleh sebab itu, penelitian ini dilakukan untuk melihat bagaimana pengelolaan model pelatihan, dan penilaian kinerja Sumber Daya Manusia di Homeschooling Kak Seto.

\section{KAJIAN TEORI}

Dalam Kamus Bahasa Indonesia Lengkap, makna dari kata pengelolaan adalah proses atau cara perbuatan mengelola atau proses melakukan kegiatan tertentu dengan menggerakkan tenaga orang lain, proses yang membantu merumuskan kebijaksanaan dan tujuan organisasi atau proses yang memberikan pengawasan pada semua hal yang terlibat dalam pelaksanaan kebijaksanaan dan pencapai tujuan.

Marry Parker Follet (1997) mendefinisikan pengelolaan adalah seni atau proses dalam menyelesaikan sesuatu yang terkait dengan pecapaian tujuan. Dalam penyelesaian akan sesuatu tersebut, terdapat tiga faktor yang terlibat:

a) Adanya penggunaan sumber daya organisasi, baik sumber daya manusia maupun faktor-faktor produksi lainya.

b) Proses yang bertahap mulai dari perencanaan, pengorganisasian, pengarahan dan pengimplementasian, hingga pengendalian dan pengawasan.

c) Adanya seni dalam penyelesaian pekerjaan.

Jadi secara umum, pengelolaan dapat diartikan sebagai suatu rangkaian pekerjaan atau usaha yang dilakukan oleh sekelompok orang untuk melakukan serangkaian kerja dalam mencapai tujan tertentu. Pengelolaan merupakan kegiatan merubah sesuatu.hingga menjadi baik serta memiliki nilai-nilai yang tinggi dari semula. Pengelolaan dapat juga diartikan sebagai untuk melakukan sesuatu agar lebih sesuai serta cocok dengan kebutuhan sehingga lebih bermanfaat.

Menurut H.Teman Koesmono (2006. hlm.9) Seseorang akan senantiasa mendambakan penghargaan terhadap hasil kerjanya dan tentu mengharapkan imbalan yang adil, penilaian kinerja perlu dilakukan seobyektif mungkin karena akan memotivasi karyawan dalam melakukan pekerjaannya, disamping itu juga penilaian kinerja dapat memberikan informasi untuk kepentingan pemberian gaji, promosi, dan melihat perilaku karyawan. Wildman (1994) mengatakan kinerja merupakan gabungan perilaku dengan prestasi dari apa yang diharapkan dan pilihannya atau bagian syarat-syarat tugas yang ada pada masing-masing individu dalam organisasi, sedangkan menurut mangkunegara $(2001 ; 67)$ kinerja dapat didefinisikan sebagai hasil kerja secara kualitas dan kuantitas yang dapat dicapai oleh seseorang pegawai dalam melaksanakan tugas sesuai dengan tanggung jawab yang diberikan. Cascio $(1995 ; 275)$ mengatakan juga bahwa kinerja merupakan prestasi karyawan dari tugas-tugasnya yang telah ditetapkan, kemudian Soeprihantono $(1988 ; 7)$ berpendapat kinerja merupakan hasil pekerjaan seorang karyawan selama periode tertentu dibandingkan dengan berbagai kemungkinan, misalkan target, sasaran ataupun kriteria yang telah ditentukan terlebih dahulu dan disepakati bersama.

Ali Muhtadi (2011,hlm.4-5) mengungkapkan pengertian dan karakteristik Home 
schooling, Home schooling secara etimologis dapat dimaknai sebagai sekolah rumah. Namun pada hakekatnya home schooling merupakan sebuah sekolah alternatif yang mencoba menempatkan anak sebagai subjek belajar dengan pendekatan pendidikan secara at home. Yang dimaksud dengan at home adalah pendekatan kekeluargaan yang memungkinkan anak belajar dengan nyaman sesuai dengan keinginan dan gaya belajar masing-masing, kapan saja, dimana saja dan dengan siapa saja. Dengan pendekatan ini diharapkan anak bisa tumbuh kembang secara lebih wajar dan optimal tanpa terkekang potensinya.

\section{METODE PENELITIAN}

Dalam penelitian ini menggunakan rancangan penelitian kualitatif dengan pendekatan deskriptif kualitatif merupakan acuan bagi peneliti dalam pelaksanaan penelitian karena dalam penelitian ini menggambarkan secara sistematik dan akurat atas fakta dan karakteristik mengenai bidang tertentu.bagaimana peneliti memperoleh data yang valid dan reliable sehingga mampu menjawab masalah yang sedang diteliti. Lokasi Penelitian dilakukan di Homeschooling Kak Seto yang berada di Jl. Taman Makam Bahagia ABRI NO. 3A Parigi Lama, Pondok Aren, Bintaro Sektor 9 Tangerang Selatan 15227. Penelitian ini di fokuskan pada : Model pengelolaan pelatihan di HSKS dan Kinerja SDM di HSKS Instrumen penelitian terdiri dari observasi, wawancara, kuisioner atau angket yang disebar melalui google doc, dan dokumentasi.

\section{HASIL DAN PEMBAHASAN}

Dari data responden, identitas yang diisi adalah posisi dan pendidikan. Posisi Tutor sebanyak 70,8\%; administrasi 16,7\%; keuangan 4,2\%; dan SDM 8,3\%. Sedangkan pendidikan terakhirnya sebanyak 12,5\% SMA/SMK; 4,2\% D3; 75\% S1; dan 8,3\% S2.

Pada bagian model pelatihan, di perencanaan program pelatihan, peserta merasa ada keterlibatan dengan perencanaan program pelatihan yang ditunjukkan dengan angka $72,92 \%$ atau puas. Kemudian, pengelola program merencakan media pembelajaran yang mendukung dalam pelatihan sebanyak $77,08 \%$ atau sangat puas. Tiga pernyataan berikutnya dijawab puas dengan angka 72,92\% mengenai pelaksanaan pelatihan sesuai dengan perencanaan, $71,88 \%$ mengenai kesesuaian antara struktur organisasi dengan prosedur pengorganisasian peserta pelatihan, dan $66,67 \%$ keterlibatan berbagai instansi dalam pengorganisasi peserta pelatihan.

Di tahap pelaksanaan pelatihan, responden menyatakan sangat puas $(80,21 \%)$ bahwa pengurus berperan aktif selama pengorganisasian peserta pelatihan. Lima pernyataan berikutnya dinyatakan puas, yaitu sebanyak $71,88 \%$ pelatihan sesuai dengan rundown acara, $75 \%$ metode pembelajaran yang digunakan pada saat pelatihan menarik, $73,96 \%$ pengelola pelatihan menentukan waktu pelaksanaan, $70,83 \%$ tempat pelatihan memenuhi syarat pelatihan, $72,92 \%$ pelatihan ditunjang dengan media yang inovatif. Mengenai penyediaan tutor, responden sangat puas karena tutor aktif dalam pembelajaran yang dinyatakan sebanyak $78,13 \%$. Keterlibatan peserta terhadap pelatihan dinyatakan puas, yaitu sebanyak $75 \%$.

Berkenaan dengan evaluasi, semua indikator dinyatakan puas. $69,79 \%$ peserta mengetahui bahwa panitia akan mengevaluasi selama proses pelatihan, 6,67\% peserta mengetahui komponen yang di evaluasi, $72,92 \%$ dilakuakn pendekatan evaluatif dalam mengevaluasi peserta pelatihan, $68,75 \%$ penggunaan berbagai macam alat evaluasi, $69,79 \%$ evaluasi sesuai dengan prosedur evaluasi pelatihan, dan $64,58 \%$ hasil evaluasi disampaikan pada peserta pelatihan.

Selanjutnya dalam mengukur kinerja SDM. 76,04\% menyatakan sangat setuju bahwa dirinya memiliki standar keterampilan yang sudah ditetapkan oleh pengelola dengan 
pengetahuan terhadap standar tersebut sebanyak 73,96\% dan standar yang sudah sesuai degan kebutuhan lembaga sebanyak 73,96\%. Pemberian pelatihan untuk meningkatkan kompetensi sangat disetujui oleh responden sebanyak $78,13 \%$. Demikian pula dengan motivasi lembaga yang diberikan kepada responden untuk terus meningkatkan kemampuan belajar yang sangat disetujui sebesar 79,13\%.

Menurut responden, pengalaman menjadi pembelajaran sangat berharga yang ditunjukkan dengan angka $87,50 \%$ atau sangat setuju. Hal ini pun menjadi salah satu pertimbangan pimpinan lembaga dalam merekrut karyawan karena menganggap bahwa pengalaman memberikan pengaruh positif bagi penyelesaian pekerjaan.

HSKS pun mendorong para karyawan untuk mengembangkan ide. HRD/Pengelola program menjelaskan bahwa ruang kelas dibuat sefleksibel mungkin dengan tujuan agar tutor dapat melakukan ekplorasi memberikan metode belajar pada homeschooler. Tata letak kursi dan meja terkadang dibuat melingkar, berjajar, atau bahkan tidak digunakan. Semuanya diserahkan pada tutor untuk mencari cara pembelajaran paling efektif dan menyenangkan bagi para homeschooler. Motto HSKS menyelipkan kata kreatif sebagai pacuan agar setiap karyawan berekspresi, salah satunya melalui sarana prasarana yang disediakan. Responden mengamini hal tersebut dengan menunjukkan respon sangat setuju sebesar $81,25 \%$ untuk memiliki inisiatif dalam belajar hal baru dan $73,96 \%$ atau setuju terhadap stimulus yang diberikan Yayasan untuk meningkatkan keaktifan responden.

Kebanggaan atau rasa senang para responden menjadi bagian HSKS ditunjukkan beberapa poin berikutnya. Penilaian pertama adalah reward yang diberikan atas antusias yang tinggi terhadap pembelajaran ditunjukkan dengan setuju atau 64,58\%. Kebanggaan terhadap pekerjaan ditunjukkand engan angka $82,29 \%$ atau sangat setuju. menyebutkan salah satu bentuknya melalui posting berbagai kegiatan yang sedang dilaksanakan di HSKS, tanpa arahan atau anjuran dari atasan. Sebaliknya, keluhan di media online tidak pernah ditemui oleh HRD/Pengelola program. Bukan berarti tidak ada keluhan. Akan tetapi karena karyawan memiliki fasilitas untuk mencurahkan ketidakpuasannya terhadap pekerjaan melalui SDM. Responden menyetujui pernyataan ini dengan tingkat persetujuan sebanyak $66,67 \%$.

Dengan fasilitas tersebut, menurut HRD/Pengelola program dapat meningkatkan kepuasan kerja dan situasi kondusif di lingkungan kerja. Pendapat responden pun sejalan dengan pernyataan tersebut. Sebanyak $78,13 \%$ responden menyatakan sangat setuju bahwa dirinya terlibat dalam setiap kegiatan, termasuk dengan membantu rekan yang mengalami kesulitasn sebanyak 85,42\%. Keterlibatan responden terhadap kegiatan yang dilaksanakan oleh lembaga ditunjukkan dengan $77,08 \%$ atau sangat setuju. Tidak ada pula kesulitan dalam kerjasama tim yang ditunjukkan dengan angka $71,88 \%$ dan berhasil menyelesaikan tugas tepat waktu dengan angka $77,08 \%$ dengan motivasi tinggi untuk menyelesaikan tugas sebanyak $81,25 \%$.

Karena tingkat kepuasan dan kebanggaan para karyawan yang ditunjukkan dengan skala setuju dan sangat setuju di atas, para reponden tidak memiliki keinginan untuk keluar dari HSKS yang ditunjukkan dengan $61,46 \%$ atau setuju. Para responden pun loyal dengan tidak membocorkan rahasia lembaga sebanyak $80,21 \%$ dan mendahulukan kepantingan perusahaan sebanyak $69,79 \%$. HRD/Pengelola program mencotohkan satu sikap yang dapat menjadi gambaran loyalitas para karyawan di HSKS.

Pada tahun-tahun sebelumnya, HSKS memiliki karyawan total 170 orang. Staf SDM hanya 3 orang, sehingga berbagai administrasi terlambat selesai, misalnya berkaitan dengan kontrak kerja. Hampir 70\% tanpa kontrak atau habis masa kontrak karena bagian SDM overload 
pekerjaan. Hingga saat ini, masih $30 \%$ teman-teman di HSKS yang belum punya kontrak atau tidak diperpanjang kontraknya secara administratif. Tetapi mereka masih tetap mengerjakan tugas dan kewajibannya dengan terus mengingatkan kepada departemen SDM bahwa kontraknya telah/akan habis atau bahkan belum ada. SDM akan memberikan update mengenai status pengurusan administrasi kontrak kerjanya. Dengan mengetahui informasi tersebut, pegawai merasa yakin bahwa SDM tetap mengerjakan dan mengurus kebutuhannya, walaupun mungkin sedikit terlambat.

Sekalipun di pembahasan sebelumnya, pelanggaran yang pernah dilakukan responden mencapai $50 \%$, tetapi responden sangat menyetujui bahwa ada keharusan untuk menaati peraturan HSKS yang ditunjukkan dengan angka 80,21\%. Sedangkan mengenai hubungan baik dengan rekan kerja, bentuknya seperti berbagi ilmu dan saling membantu menyelesaikan pekerjaan yang ditunjukkan dengan $82,29 \%$ atau sangat setuju dan $68,75 \%$ atau setuju.

\section{KESIMPULAN DAN REKOMENDASI}

Kesimpulan dan Saran Berdasarkan hasil analisis data tersebut, dapat disimpulkan model pengelolaan pelatihan di homeschooling kak seto melibatkan peserta dalam perencanaan, pelaksanaan, dan evaluasi kemudian kinerja sumber daya manusia di Homeschooling kak seto sudah memenuhi dengan kebutuhan lembaga.

Penulisan ini sudah menggali model pengelolaan pelatihan di Homeschooling Kak Seto dengan peningkatan kapasitas dan kinerja Sumber Daya Manusianya. Sebagai Yayasan yang menyelenggarakan pendidikan terhadap masyarakat, terutama anak, pengukuran tersebut dapat bermanfaat untuk meningkatkan kualitas SDM sehingga dapat meningkatkan penyelenggaraan layananannya. Terlebih untuk tutor yang menangani anak berkebutuhan khusus dengan latar belakang bukan pendidikan. Akan sangat menarik, dalam pandangan penulis, bagaimana seseorang yang tidak menempuh pendidikan sebagai calon guru, diterima menjadi tutor untuk anak berkebutuhan khusus. Hal ini akan menunjukkan kekuatan pelatihan sebagai salah satu upaya untuk meningkatkan kualitas sumber daya manusia.

\section{DAFTAR PUSTAKA}

Arikunto,2006 "Prosedur dan penilitian suatu pendekatan praktik :Jakarta,Reineka Cipta

Koesmono H.T (2006) "Pengaruh Budaya organisasi terhadap motivasi dan kepuasan kerja serta kinerja karyawan pada sub sektor industri pengelolaan kayu skala menengah di jawa timur. Jurnal manajemen dan kewirausahaan, hlm.9

Kamus Besar Bahasa Indonesia (KBBI) Lengkap

Muhtadi.A (2011) "Pendidikan dan pembelajaran di sekolah rumah (Home Schooling) suatu tinjauan teori dan praktis",(hlm.4-5,hlm.9-10 \& hlm.16)

Sugiyono,Prof.Dr "Metode penilitian pendidikan"Bandung :Alfabeta

Suryadi, Ace. 2012. Pendidikan, Investasi SDM, dan Pembangunan: Isu, Teori, dan Aplikasi untuk Pembangunan Pendidikan dan Sumber Daya Manusia Indonesia. Bandung: Widya Aksara Press. 